\title{
THE HEAT-STABLE CYTOSOLIC FACTOR THAT PROMOTES GLUCOCORTICOID RECEPTOR BINDING TO DNA IS NEITHER THIOREDOXIN NOR RIBONUCLEASE
}

\author{
Wilai Tienrungroj*, Sean E. Pratt*, Joseph F. Grippo*, Arne Holmgren† and \\ William B. Pratt* $\ddagger$ \\ *Department of Pharmacology, The University of Michigan Medical School, Ann Arbor, \\ MI 48109-0010, U.S.A. and the †Department of Chemistry, Karolinska Institutet, S-104 01, \\ Stockholm 60, Sweden
}

(Received 6 March 1987)

\begin{abstract}
Summary-Treatment of rat liver cytosol containing temperature-transformed $\left[{ }^{3} \mathrm{H}\right]$ dexamethasone-bound receptors at $0^{\circ} \mathrm{C}$ with the sulfhydryl modifying reagent methyl methanethiosulfonate (MMTS) inhibits the DNA-binding activity of the receptor, and DNA-binding activity is restored after addition of dithiothreitol (DTT). However, transformed receptors that are treated with MMTS and then separated from low $M$, components of cytosol by passage through a column of Sephadex G-50 have very little DNA-binding activity when DTT is added to regenerate sulfhydryl moities. The receptors will bind to DNA if whole liver cytosol or boiled liver cytosol is added in addition to DTT. The effect of boiled cytosol is mimicked by purified rat thioredoxin or bovine RNase A in a manner that does not reflect the reducing activity of the former or the catalytic activity of the latter. This suggests that the reported ability of each of these heat-stable peptides to stimulate DNA binding by glucocorticoid receptors is not a biologically relevant action. We suggest that stimulation of DNA binding of partially purified receptors by boiled cytosol does not constitute a reconstitution of a complete cytosolic system in which the dissociated receptor must associate with a specific heat-stable accessory protein required for DNA binding, as has been suggested in the "two-step" model of receptor transformation recently proposed by Schmidt et al. (Schmidt T. J., Miller-Diener, A., Webb M. L. and Litwack G. (1985) J. biol. Chem. 260, 16255-16262).
\end{abstract}

\section{INTRODUCTION}

Sulfhydryl groups are important for permitting several actions of steroid receptors. For example, SH-groups are required for glucocorticoid receptors in cytosol preparations to bind steroid [1], and subsequently, for transformed $\S$ glucocorticoid-receptor complexes to bind to DNA [2]. Bodwell et al.[3] have provided good evidence that the sulfhydryl groups required for DNA binding by the transformed receptor are different from those required for steroid binding. In addition, there is evidence that sulfur moieties must be in a reduced form for progesterone [4], androgen [5] and glucocorticoid [6]

¥To whom correspondence should be addressed.

\$It should be noted that we will use the term "transformation" to describe the process whereby the steroidbound receptor is converted to a form that binds to nuclei, DNA-cellulose, etc. We have used the term "activation" to describe the process whereby the oxidized receptor is converted from a nonbinding form to a form that binds steroids.

IW. Tienrungroj, S. Meshinchi, E. R. Sanchez, S. E. Pratt, J. F. Grippo, A. Holmgren and W. B. Pratt, Manuscript submitted for publication.

Abbreviations: MMTS, methyl methanethiosulfonate; Hepes, 4-(2-hydroxyethyl)-1-piperazine ethanesulfonic acid; DTT, dithiothreitol. receptors to undergo transformation. Our laboratory has been interested in defining the endogenous heatstable cytosolic factors that are responsible for converting glucocorticoid receptors from a non-steroidbinding to a steroid-binding form $[7,8]$. We have published evidence that glucocorticoid receptors in rat liver cytosol are maintained in a reduced, steroidbinding state by a NADPH-dependent, thioredoxinmediated thiol-disulfide interchange system $[9,10]$.

Recently, in pursuing studies on receptor transformation to the DNA-binding state, we have considered a second possible interaction of thioredoxin with the glucocorticoid receptor [11]. We began by asking whether an enzyme was involved in temperature-mediated transformation of the glucocorticoid-receptor complex. Rat liver cytosol containing untransformed steroid-bound receptor was passed through a column of Bio-Gel ASM (in molybdate-free buffer) to separate the receptor from smaller cytosolic components that might be required for transformation. The fractions containing the steroid-receptor complex were combined and rapidly concentrated back to the original sample volume by filtration on an Amicon filter. The steroid-receptor complex in this Bio-Gel peak had little DNA binding activity, and in contrast to untreated cytosol, when the peak material was heated at $25^{\circ} \mathrm{C}$, there was little or no increase in DNA binding [11]. 
As the Bio-Gel-separated complex did not show increased binding when it was heated, it seemed possible that it had been separated from a smaller cytosolic component (or components) required for subsequent temperature-mediated transformation. Accordingly, we added either whole cytosol (containing inactivated receptors) or boiled cytosol to the Bio-Gel-separated glucocorticoid-receptor complex and found that both cytosol preparations permitted increased binding of receptors to DNA-cellulose [11]. Not only was the boiled cytosol effective at increasing the DNA binding, but it was effective at $0^{\circ} \mathrm{C}$. These observations suggested that a heat-stable component of cytosol was promoting DNA binding in a nonenzymatic manner. The activity in boiled cytosol behaved like thioredoxin in that it was smaller than the excluded material on Sephadex G-50 chromatography $\left(M_{r}<30,000\right)$, but most of it did not pass through an Amicon YM10 filter $\left(M_{r}>10,000\right)$. Therefore, we added purified rat liver thioredoxin to the Bio-Gel-separated receptors and found that it was as active as boiled cytosol in promoting DNA binding [11].

Taken together, these observations led us to speculate that thioredoxin might be involved in the binding of transformed receptor to DNA [11]. Thioredoxin could act either by reducing the sulfur moieties required for DNA binding, or possibly by binding to the receptor itself and producing a conformational change leading to an increased affinity for DNA. Thioredoxin is known, for example, to bind tightly to bacteriophage T7 DNA polymerase and through a conformational rather than a reductive action it permits the enzyme to function on double-stranded nucleic acids [12, 13]. Huber et al. [13] have speculated that thioredoxin binds to the enzyme near the binding crevice for double-stranded DNA and locks the duplex DNA into position. In this paper, we examine the effects of thioredoxin in promoting DNA binding by transformed glucocorticoid receptors whose DNA binding activity has been reversibly inactivated with a sulfhydryl modifying agent. We find that neither the effect of thioredoxin nor the similar effect produced by $\mathrm{RNase}$ in this system reflects a biologically relevant action of these heat-stable peptides.

\section{Materials}

\section{EXPERIMENTAL}

$\left[6,7-{ }^{3} \mathrm{H}\right]$ Dexamethasone $(45.8 \mathrm{Ci} / \mathrm{mmol})$ was obtained from New England Nuclear, Boston, MA. Insulin isolated from bovine pancreas, dithiothreitol, nonradioactive dexamethasone, methyl methanethiosulfonate, ribonuclease A (EC 3.1.27.5) from bovine pancreas (Type XII-A), ribonuclease Sprotein from bovine pancreas (Grade XII-PE) were obtained from J. T. Baker Chemical Co., Phillipsburg, New Jersey.

\section{Cell source and fractionation}

Liver was obtained from $100-200 \mathrm{~g}$ male
Sprague-Dawley rats which had been adrenalectomized and maintained on $9 \%$ saline for 1 day,prior to sacrifice. Livers were removed immediately upon death, placed in ice-cold Earle's balanced salt solution, and homogenized in a Waring blender in $1.5 \mathrm{vol}$ of $10 \mathrm{mM}$ Hepes buffer, pH 7.35, per gram of wet weight, followed by Dounce homogenization. The tissue homogenate was centrifuged for $20 \mathrm{~min}$ at $27,000 \mathrm{~g}$ and the resulting supernatant was centrifuged at $100,000 \mathrm{~g}$ for $2 \mathrm{~h}$. The $100,000 \mathrm{~g}$ supernatant (referred to as cytosol) was used as the source of receptor, and was stored at $-70^{\circ} \mathrm{C}$ until used.

\section{Incubation conditions and steroid binding assay}

Incubations containing cytosol and other additions were prepared as noted in the figure and table legends. Most additions were made from stock solutions concentrated at least 10 -fold. The cytosol was preincubated at $0^{\circ} \mathrm{C}$ with $50 \mathrm{mM}\left[{ }^{3} \mathrm{H}\right]$ dexamethasone, with or without a 1000 -fold excess of nonradioactive dexamethasone, for at least $3 \mathrm{~h}$ to form bound receptor and was then subjected to the various experimental conditions. The steroid-receptor complexes were first transformed to the DNA-binding state by incubating the cytosol for $45 \mathrm{~min}$ at $25^{\circ} \mathrm{C}$. Cytosol containing transformed $\left[{ }^{3} \mathrm{H}\right]$ dexamethasone-receptor complexes was then incubated for $1 \mathrm{~h}$ on ice with 3 or $3.5 \mathrm{mM}$ MMTS to inactivate DNA-binding capacity. To reverse the MMTS inhibition of DNA binding in whole cytosol, DTT $(20 \mathrm{mM})$ was added to the indicated samples and steroid binding and DNA binding were assayed.

Transformed steroid-receptor complexes that had been treated with MMTS in whole cytosol were separated from free MMTS and small $M_{r}(<30,000)$ components of cytosol by passage through a column $(2.5 \times 83 \mathrm{~cm})$ of Sephadex G-50, eluting with $10 \mathrm{mM}$ Hepes buffer, pH 7.35. The column eluate was monitored at $280 \mathrm{~nm}$, and the fractions containing the macromolecular material (void volume peak) were pooled and concentrated to original volume by filtration on an Amicon YM10 filter which excludes molecules of $M_{r}$ greater than approx 10,000 . This preparation was then incubated on ice for 1 hour with DTT and other additions (as indicated in the figure and table legends) to permit reactivation of DNAbinding capacity prior to assay of steroid binding and binding to DNA-cellulose.

\section{Assay of steroid binding and binding to DNA-cellulose}

Steroid binding was assayed by the charcoal absorption method. Aliquots of each incubation mixture $(0.1 \mathrm{ml})$, preincubated with steroid as described above, were incubated with $0.15 \mathrm{ml}$ of a suspension of dextran-coated charcoal ( $1 \%$ charcoal $(w / v)$ and $0.2 \%$ dextran $(w / v)$ in $10 \mathrm{mM}$ Hepes, $\mathrm{pH} 7.35$, at $4^{\circ} \mathrm{C}$ ) for $10 \mathrm{~min}$ at $0^{\circ} \mathrm{C}$. After centrifugation at $12,000 \mathrm{~g}$ for $4 \mathrm{~min}, 0.1 \mathrm{ml}$ of the supernatant was assayed for radioactivity in $5 \mathrm{ml}$ of scintillation fluid. The specific binding represents the average of dupli- 
cate assays made in the absence of competing dexamethasone minus the nonspecific binding value and is expressed in cpm $/ 0.2 \mathrm{ml}$ of original undiluted cytosol. In samples of MMTS-treated cytosol that were passed through Sephadex G-50, all of the bound steroid recovered in the macromolecular peak was considered to represent steroid-receptor complex. The assumption is valid, as a control experiment in which a nonspecifically bound sample was passed through the column revealed no binding in the macromolecular peak.

To assay DNA binding, duplicate $0.1 \mathrm{ml}$ aliquots of incubation mix were incubated for $45 \mathrm{~min}$ with $0.1 \mathrm{ml}$ of a suspension of DNA-cellulose under constant stirring in an ice bath. The DNA-cellulosebound material was washed and assayed for radioactivity as described previously [8]. DNA-cellulose was used as a $12.5 \%(\mathrm{v} / \mathrm{v})$ suspension of DNAcellulose $(0.36 \mathrm{mg}$ of native $\mathrm{DNA} / \mathrm{ml}$ of cellulose).

\section{Preparation of the endogenous activating factor}

The endogenous receptor activating factor (partially purified thioredoxin), which is called EAF in the legends to the tables and figures, was prepared from the $27,000 \mathrm{~g}$ supernatant of rat liver essentially as previously described [9]. Briefly, the $27,000 \mathrm{~g}$ supernatant fraction from rat liver was placed into a boiling water bath for $2 \mathrm{~min}$ and the denatured protein was removed by centrifuging at $27,000 \mathrm{~g}$ for $5 \mathrm{~min}$. One hundred $\mathrm{ml}$ of the boiled supernatant were lyophilized to dryness, redissolved in $10 \mathrm{ml}$ of

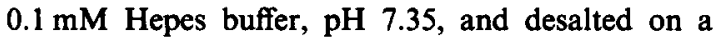
Sephadex G-50 column $(2.5 \times 67 \mathrm{~cm})$. All of the fractions obtained prior to the salt peak were pooled, lyophilized, dissolved in $4 \mathrm{ml}$ of $0.1 \mathrm{mM}$ Hepes buffer, pH 7.35, and incubated with $10 \mathrm{mM}$ DTT for $30 \mathrm{~min}$ at $20^{\circ} \mathrm{C}$ to reduce all thioredoxin in the preparation. This material was applied to another Sephadex G-50 column $(2.5 \times 80 \mathrm{~cm})$ and eluted with $0.1 \mathrm{mM}$ Hepes buffer, pH 7.35. The eluent was monitored at $280 \mathrm{~nm}$ and aliquots from every other fraction were assayed for thioredoxin activity by the insulin disulfide reduction method described below. The thioredoxincontaining fractions, which are eluted in the same fractions as the endogenous receptor activating activity [9], were pooled, lyophilized to dryness and stored at $-20^{\circ} \mathrm{C}$ until used.

\section{Thioredoxin assay}

Thioredoxin was assayed by the insulin disulfide reduction method of Holmgren[14]. An aliquot of each test sample was incubated in a final volume of $0.6 \mathrm{ml}$ in a $1 \mathrm{ml}$ cuvette at room temperature with $500 \mu \mathrm{l}$ of bovine insulin $(1 \mathrm{mg} / \mathrm{ml}), 8 \mu 1$ of $50 \mathrm{mM}$ dithiothreitol, and the appropriate volume of $100 \mathrm{mM}$ phosphate buffer, $\mathrm{pH} 7.0$, containing $2-\mathrm{mM}$

*W. Tienrungroj, S. Meshinchi, E. R. Sanchez, S. E. Pratt, J. F. Grippo, A. Holmgren and W. B. Pratt, Manuscript submitted for publication.
EDTA. Measurements were performed at $\mathrm{A}_{650}$ every 5-10 min. Rates of insulin reduction were expressed as the change in turbidity with time observed within a linear range between 0.2 and $1.0 \mathrm{~A}_{650}$. The nonenzymatic reduction of insulin by dithiothreitol was recorded in a control cuvette without thioredoxin and this value $\left(0.008-0.01 A_{650 \mathrm{~nm}} \times \mathrm{min}^{-1}\right)$ was subtracted from that recorded with each test sample to yield the rate of insulin reduction due to thioredoxin. A standard curve generated from purified rat liver thioredoxin was used to determine the thioredoxin concentration of the EAF preparation.

\section{Purified thioredoxin and thioredoxin antiserum}

Rat liver thioredoxin was purified to $80 \%$ of homogeneity at the Karolinska laboratory by the method of Holmgren and Luthman[15]. The purified thioredoxin $(45 \mu \mathrm{m})$ was sent to the United States in the oxidized form in $50 \mathrm{mM}$ Tris- $\mathrm{HCl}$ buffer, $\mathrm{pH} 7.5$, $8 \mathrm{mM}$ EDTA. Antiserum against purified rat liver thioredoxin was prepared in rabbits as described previously [10]. The gamma-globulin fraction of preimmune and antithioredoxin serum was prepared as described [10], precipitated to $90 \%$ of saturation with solid ammonium sulfate and the suspensions sent by airmail from Stockholm to Ann Arbor. On arrival, the precipitate was collected by centrifugation, dissolved in $10 \mathrm{mM}$ Hepes buffer, p 7.35, and dialyzed against Hepes buffer overnight. After dialysis, the sera were returned to original volume with buffer and stored in $0.2 \mathrm{ml}$ aliquots at $-20^{\circ} \mathrm{C}$ until used.

\section{RESULTS}

\section{Reversal of MMTS inhibition of DNA binding}

Methyl methanethiosulfonate (MMTS) reacts specifically with protein thiols to derivatize them by adding a thiomethyl group through the formation of a mixed disulfide. Bodwell et al.[2] have shown that $0.25 \mathrm{mM}$ MMTS is required to produce half-maximal inhibition of DNA binding by transformed glucocorticoid receptors in rat thymocyte cytosol. Tienrungroj et al.* have found that a 10-fold higher concentration of MMTS is required to inhibit DNA binding by transformed receptors in rat liver cytosol, which has a higher concentration of glutathione available to react with the reagent [9]. The inhibition of DNA binding caused by $3 \mathrm{mM}$ MMTS in whole rat liver cytosol is shown at the top of Table 1 . At this concentration of MMTS, the steroid-receptor complex is not disrupted but DNA binding is inhibited and the inhibition can be reversed by adding $10 \mathrm{mM}$ dithiothreitol (DTT) to the cytosol.

After derivatization with MMTS, sylfyhdryl groups can be regenerated by reagents, like DTT, which promote thiol-disulfide interchange. If regeneration of receptor sulfhydryl groups is the only thing that is required to permit the MMTS-treated, transformed receptor to bind to DNA, then MMTS-treated 
Table 1. Small, heat-stable components of cytosol are required in addition to DTT to reverse MMTS inhibition of DNA binding

\begin{tabular}{lcccc}
\hline Condition & Expt & $\begin{array}{c}\text { Specific } \\
\text { binding }\end{array}$ & $\begin{array}{c}\text { Binding to } \\
\text { DNA-cellulose }\end{array}$ & $\begin{array}{c}\text { \% of total } \\
\text { complexes bound } \\
\text { to DNA-cellulose }\end{array}$ \\
\hline Transformed cytosol alone & 1 & \multicolumn{2}{c}{$\mathrm{cpm} / 0.2 \mathrm{ml}$} \\
& 29,600 & 8760 & 30 \\
plus MMTS & 1 & 20,400 & 9270 & 45 \\
& 2 & 33,100 & 4960 & 15 \\
plus MMTS then DTT & 1 & 17,700 & 4400 & 25 \\
& 2 & 20,200 & 8120 & 25 \\
MMTS-treated cytosol filtered & & & 7940 & 40 \\
through Sephadex G-50 & 1 & 20,000 & & \\
no additions & 2 & 10,100 & 860 & 6 \\
plus DTT & 1 & 21,700 & 2270 & 10 \\
plus whole cytosol & 2 & 11,900 & 1850 & 16 \\
plus whole cytosol and DTT & 1 & 20,800 & 2500 & 12 \\
plus boiled cytosol & 1 & 21,800 & 4590 & 21 \\
& 1 & 21,100 & 2220 & 11 \\
plus boiled cytosol and DTT & 2 & 12,000 & 2530 & 21 \\
& 1 & 20,400 & 4250 & 21 \\
& 2 & 11,600 & 4360 & 38 \\
\hline
\end{tabular}

Rat liver cytosol containing $\left[{ }^{3} \mathrm{H}\right]$ dexamethasone-bound, temperature-transformed receptors was incubated for $1 \mathrm{~h}$ on ice with $3 \mathrm{mM}$ MMTS to reduce the DNA-binding activity of the receptor. A portion of MMTS-treated cytosol was then maintained at $0^{\circ} \mathrm{C}$ while the remainder was filtered through a column of Sephadex G-50 to separate the steroid-receptor complex from unreacted MMTS and from small components of cytosol. The fractions containing the material in the Sephadex void volume peak were concentrated back to original volume by Amicon filtration. Additions of whole rat liver cytosol or boiled rat liver cytosol (each at $40 \%$ of final incubation volume) or DTT $(10 \mathrm{mM})$ were made as indicated and both steroid binding and binding to DNA-cellulose were assayed $1 \mathrm{~h}$ later. Receptors in whole cytosol were inactivated by incubation at $37^{\circ} \mathrm{C}$ prior to addition. MMTS treated cytosol that was not filtered through Sephadex G-50 was maintained at $0^{\circ} \mathrm{C}$ and DTT was added to restore DNA-binding activity $5 \mathrm{~h}$ later, which is the time required for the rest of the material to be run through the Sephadex and Amicon procedures. The results of two experiments are presented. The DNA-binding capacity of the untransformed, $0^{\circ} \mathrm{C}$ control cytosol was $1820 \mathrm{cpm} / 0.2 \mathrm{ml}$ in experiment 1 and $900 \mathrm{cpm} / 0.2 \mathrm{ml}$ in experiment 2 .

receptors that have been separated from unreacted MMTS and small $M_{r}$ components of cytosol should be returned to the DNA binding state by exposing them to DTT alone. In the experiments shown in Table 1, temperature-transformed receptors were treated with MMTS and the cytosol was then filtered through a column of Sephadex G-50 to separate
MMTS-treated receptor from any unreacted MMTS and small $M$, cytosol components $(<30,000)$. This procedure takes several hours and is accompanied by a loss of $20-50 \%$ of the steroid binding. Transformed receptors treated in this manner have a very low DNA binding activity that is only partially restored by DTT. Readdition of cytosol components in the

Table 2. Reversal of MMTS inhibition of DNA binding by DTT and the endogenous receptor activating factor or purified thioredoxin

\begin{tabular}{|c|c|c|c|}
\hline Condition & $\begin{array}{l}\text { Specific } \\
\text { binding }\end{array}$ & $\begin{array}{c}\text { Binding to } \\
\text { DNA-cellulose }\end{array}$ & $\begin{array}{l}\% \text { of total } \\
\text { complexes bound to } \\
\text { DNA-cellulose }\end{array}$ \\
\hline & \multicolumn{2}{|c|}{$\mathrm{cpm} / 0.2 \mathrm{ml}$} & \\
\hline Transformed cytosol alone & 31,400 & 12,800 & 41 \\
\hline plus MMTS & 40,500 & 6430 & 16 \\
\hline plus MMTS then DTT & 44,200 & 14,000 & 32 \\
\hline \multicolumn{4}{|l|}{$\begin{array}{l}\text { MMTS-treated cytosol filtered } \\
\text { through Sephadex G-50 }\end{array}$} \\
\hline plus buffer alone & 29,600 & 1610 & 5 \\
\hline plus DTT & 29,600 & 2490 & 8 \\
\hline plus boiled cytosol & 32,900 & 7760 & 24 \\
\hline plus boiled cytosol and DTT & 31,600 & 10,200 & 32 \\
\hline plus EAF & 32,300 & 6890 & 21 \\
\hline plus EAF and DTT & 30,900 & 10,500 & 34 \\
\hline plus thioredoxin & 31,300 & 3960 & 13 \\
\hline plus thioredoxin and DTT & 29,000 & 10,100 & 35 \\
\hline
\end{tabular}

Rat liver cytosol containing [ $\left.{ }^{3} \mathrm{H}\right]$ dexamethasone-bound, temperature-transformed receptors was incubated for $1 \mathrm{~h}$ on ice with $3.5 \mathrm{mM}$ MMTS and filtered through Sephadex G-50 as described in the Legend to Table 1. Additions of boiled rat liver cytosol (at $40 \%$ of final incubation volume), endogenous activating factor (EAF, $40 \%$ by volume), or purified thioredoxin $(4.5 \mu \mathrm{mol})$, or each of these preincubated for $1 \mathrm{~h}$ at room temperature with $20 \mathrm{mM}$ DTT were made as indicated, and the mixtures were incubated on ice for $1 \mathrm{~h}$ prior to assay of steroid binding and binding to DNA-cellulose. The concentration of DTT in the incubation with the receptor was $10 \mathrm{mM}$. MMTS-treated cytosol that was not filtered through Sephadex was reactivated by addition of DTT after $1 \mathrm{~h}$. 
form of whole cytosol or boiled cytosol yields a modest increase in DNA binding. The presence of both boiled cytosol and DTT yields more DNA binding than expected from an addition of the two effects; although the percent of total steroid-receptor complexes bound to DNA-cellulose is not as high as that in the original temperature-transformed cytosol before MMTS treatment. This observation suggested to us that the MMTS-derivatized receptor may have been separated from a heat-stable component of whole cytosol that promotes receptor binding to DNA.

In the light of our previous results with Bio-Gelseparated receptors [11], we considered the possibility that thioredoxin might act like boiled cytosol to permit. DNA binding. As thioredoxin is a thiolcontaining, heat-stable protein of $M_{r} 12,000$, it would be inactivated by MMTS and separated from the receptor during the Sephadex G-50 procedure em-

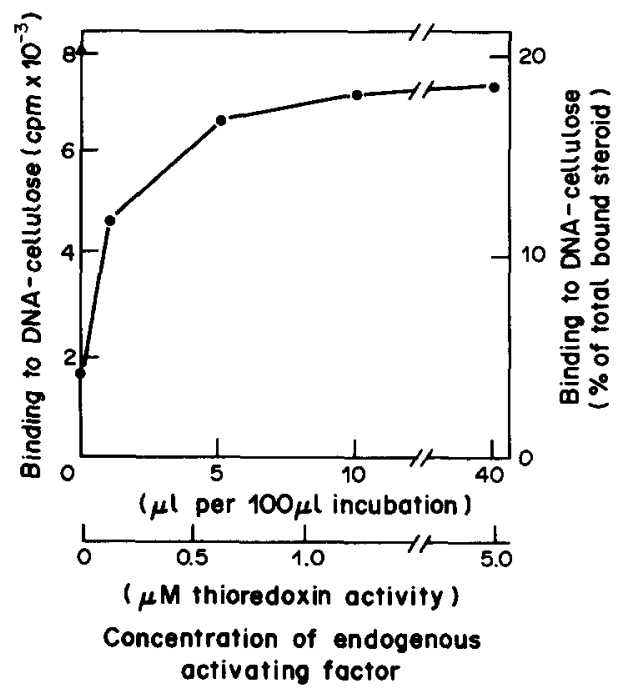

Fig. 1. Effect of a partially purified preparation of thioredoxin (EAF) on DNA-cellulose binding activity of transformed receptors that have been treated with MMTS and passed through Sephadex G-50. Rat liver cytosol containing [ ${ }^{3} \mathrm{H}$ ]dexamethasone-bound transformed receptors was treated with $3.5 \mathrm{mM}$ MMTS and filtered through Sephadex G-50 as described in the legend to Table 1. The Sephadexfiltered receptor preparation was divided into replicate aliquots which were incubated for $1 \mathrm{~h}$ on ice with $10 \mathrm{mM}$ DTT in the presence of boiled cytosol $(\boldsymbol{A})$, which was present at $40 \%$ of the final incubation volume, or with various amounts of the endogenous activating factor, EAF (O). The EAF was prepared from boiled rat liver cytosol by Sephadex chromatography as described under Experimental. In this experiment boiled cytosol and the EAF were preincubated at $25^{\circ} \mathrm{C}$ for $30 \mathrm{~min}$ with $10 \mathrm{mM}$ DTT and cooled to $4^{\circ} \mathrm{C}$ prior to addition to the Sephadex-filtered receptor preparation. Binding to DNA-cellulose is presented both as cpm/ $/ 0.2 \mathrm{ml}$ of undiluted cytosol and as the percent of total steroid-receptor complexes (assayed by charcoal assay) bound to DNA. The concentration of EAF is expressed both as the number of microliters of EAF added to the incubation and as the final concentration of thioredoxin activity, which was assayed in the EAF preparation by insulin disulfide reduction method using purified rat liver thioredoxin as standard. ployed in the experiments of Table 1. Accordingly, in the experiment of Table 2 a preparation of partially purified rat liver thioredoxin or a preparation of highly purified thioredoxin was added back to MMTS-treated receptors that were passed through Sephadex G-50. The partially purified thioredoxin was originally called endogenous activating factor (EAF) on the basis of its ability to activate the oxidized glucocorticoid receptor to its steroid binding form [9] and we will refer to it here as EAF. As shown in Table 2, both EAF and rat liver thioredoxin purified to $80 \%$ of homogeneity were as effective as boiled cytosol in permitting Sephadex-separated, MMTS-treated, transformed receptors to bind to DNA in the presence of DTT. As shown in Fig. 1, the EAF preparation is maximally effective when it is present in the system at a concentration of about 1 micromolar based on its thioredoxin activity as assayed by the insulin disulfide reduction method. The concentration of thioredoxin in the boiled rat liver cytosol is 3-4 micromolar [9] and its is being added to the Sephadex-separated receptor system at $40 \%$ of the assay volume, yielding a final concentration of 1-1.5 micromolar thioredoxin. Thus, the EAF preparation promotes receptor binding to DNA at concentrations of thioredoxin activity that exist in rat liver cytosol.

The stimulation of DNA binding by thioredoxin is not inhibited by thioredoxin antiserum

If stimulation of DNA binding by Sephadexseparated, MMTS-treated receptors is specifically permitted by thioredoxin, then one might expect the effect to be blocked by thioredoxin antiserum. A rabbit antiserum against rat thioredoxin has been prepared, and as shown in Fig. 2, when the antiserum is present at high concentration in the insulin

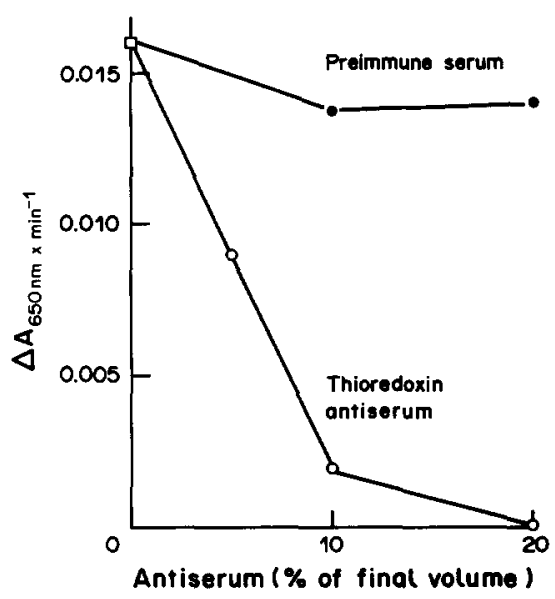

Fig. 2. Effect of thioredoxin antiserum on the reduction of insulin by a reducing system composed of dithiothreitol and EAF. The rate of insulin reduction by EAF and DTT in the presence of buffer $(\square)$, preimmune control serum ( $)$, or thioredoxin antiserum (O) was determined as described under 'Experimental'. EAF was present at $7.5 \%$ of final incubation volume ( $45 \mu 1$ in a total assay volume of $600 \mu 1)$. 
Table 3. Failure of thioredoxin antiserum to affect reversal of MMTS inhibition by DTT and partially purified thioredoxin (EAF)

\begin{tabular}{lcc}
\hline Condition & $\begin{array}{c}\text { Binding to } \\
\text { DNA-cellulose }\end{array}$ & $\begin{array}{c}\% \text { of total } \\
\text { complexes bound to } \\
\text { DNA-cellulose }\end{array}$ \\
\hline MMTS-treated cytosol filtered & cpm/0.2 ml & \\
through Sephadex G-50 & & \\
plus Buffer & 2040 & 5 \\
plus DTT & 1900 & 4 \\
plus EAF & 3750 & 9 \\
plus DTT + EAF & 9490 & 24 \\
plus DTT + EAF + preimmune serum & 8720 & 24 \\
plus DTT + EAF + immune serum & 9960 & 27 \\
\hline
\end{tabular}

Rat liver cytosol containing $\left[{ }^{3} \mathrm{H}\right]$ dexamethasone-bound, temperature-transformed receptors was incubated for $1 \mathrm{~h}$ with $3.5 \mathrm{mM}$ MMTS and filtered through Sephadex G-50. Additions of DTT (10 mM, endogenous activating factor (EAF, 40\% by volume), or EAF preincubated with preimmune or immune serum were made as indicated. The mixtures were incubated on ice for $1 \mathrm{~h}$, and steroid binding and binding to DNA-cellulose were assayed. EAF was preincubated with $35 \%$ immune or preimmune serum at $25^{\circ} \mathrm{C}$ for $30 \mathrm{~min}$, DTT was added and the preincubation was continued for an additional hour on ice prior to adding the mixture to Sephadex G-50 filtered cytosol. The concentration of antiserum in the final incubation mix containing the receptor was $17 \%$ by volume.

disulfide reduction assay, there is an immune-specific inhibition of the protein reducing activity of EAF. As shown in Table 3, however, the presence of a high concentration of antiserum did not affect stimulation of receptor binding to DNA caused by the combination of EAF and DTT. As the same concentration of antiserum was shown to inhibit the reducing function of the partially purified thioredoxin in Fig. 2, it is clear that the reducing function of thioredoxin is not required for the effect on receptor binding to DNA.

\section{RNase also stimulates DNA binding}

Grandics et al.[16] have reported that rat liver glucocorticoid-receptor complexes which have been purified approx 4000 -fold in the untransformed form by affinity chromatography undergo little conversion to the DNA-binding state when they are heated, but DNA binding can be conferred on the purified complexes in a reconstituted system in which crude cytosol has been added. The active component in rat liver cytosol was found to be a trypsin-sensitive, heat-stable $\left(90^{\circ} \mathrm{C}\right.$ for $\left.30 \mathrm{~min}\right)$ factor that is excluded from Sephadex G-25 [17]. The factor promotes DNA binding by purified receptors that have been thermally transformed and it is active at $0^{\circ} \mathrm{C}$. This led Schmidt et al.[17] to propose that transformation is a "two-step" process, with the first step being a temperature-mediated dissociation of the receptor and the second being an interaction of the dissociated receptor with a heat-stable cytoplasmic protein that enhances its ability to bind to DNA-cellulose.

Schmidt et al.[18] have recently shown that RNase

Table 4. Effect of RNase A, S-protein and S-peptide on receptor binding to DNA

\begin{tabular}{|c|c|c|c|}
\hline Condition & $\begin{array}{l}\text { Specific } \\
\text { binding }\end{array}$ & $\begin{array}{l}\text { Binding to } \\
\text { DNA-cellulose }\end{array}$ & $\begin{array}{l}\% \text { of total } \\
\text { complexes bound } \\
\text { to DNA-cellulose }\end{array}$ \\
\hline & \multicolumn{2}{|c|}{$\mathrm{cpm} / 0.2 \mathrm{ml}$} & \\
\hline Transformed cytosol alone & 57,900 & 20,400 & 35 \\
\hline plus MMTS & 55,100 & 7340 & 13 \\
\hline plus MMTS then DTT & 58,000 & 13,400 & 23 \\
\hline $\begin{array}{l}\text { MMTS-treated cytosol filtered } \\
\text { through Sephadex G-50 }\end{array}$ & & & \\
\hline plus buffer alone & 43,900 & 2450 & 6 \\
\hline plus DTT & 45,200 & 3730 & 8 \\
\hline plus boiled cytosol & 47,200 & 9210 & 20 \\
\hline plus boiled cytosol and DTT & 40,000 & 11,900 & 30 \\
\hline plus EAF & 51,900 & 9470 & 18 \\
\hline plus EAF and DTT & 46,000 & 10,600 & 23 \\
\hline plus RNase & 45,800 & 10,100 & 22 \\
\hline plus RNase and DTT & 44,100 & 12,300 & 28 \\
\hline plus S-protein & 46,600 & 5200 & 11 \\
\hline plus S-protein and DTT & 45,800 & 8000 & 17 \\
\hline plus $S$-peptide & 45,700 & 1770 & 4 \\
\hline plus $\mathrm{S}$-peptide and DTT & 45.600 & 2810 & 6 \\
\hline
\end{tabular}

Rat liver cytosol containing temperature-transformed $\left[{ }^{3} \mathrm{H}\right]$ dexamethasone-bound receptors was incubated for $1 \mathrm{~h}$ on ice with $3.5 \mathrm{mM}$ MMTS and filtered through Sephadex G.50. Additions of endogenous activating factor (EAF, $40 \%$ by volume, final protein concentration $0.68 \mathrm{mg} / \mathrm{ml})$, RNase A $(0.68 \mathrm{mg} / \mathrm{ml})$, an equimolar amount of RNase S-protein, or S-peptide, or each of these preincubated for $1 \mathrm{~h}$ at room temperature with $20 \mathrm{mM}$ DTT were made as indicated, and the mixtures were incubated on ice for $1 \mathrm{~h}$ prior to assay of steroid binding and binding to DNA-cellulose. The concentration of DTT in the incubation with the receptor is $10 \mathrm{mM}$. MMTS-treated cytosol that was not filtered through Sephadex was reactivated by addition of DTT after $1 \mathrm{~h}$. 
Table 5. Pretreatment of EAF, RNase or S-protein with $N$-ethylmaleimide does not affect their ability to promote receptor binding to DNA

\begin{tabular}{lcc}
\hline Condition & $\begin{array}{c}\text { Binding to } \\
\text { DNA-cellulose }\end{array}$ & $\begin{array}{c}\% \text { of total } \\
\text { complexes bound to } \\
\text { DNA-cellulose }\end{array}$ \\
\hline & cpm/0.2 ml & 31 \\
Transformed cytosol alone & 13,700 & 17 \\
plus MMTS & 7590 & 33 \\
Plus MMTS then DTT & 14,400 & \\
MMTS-treated cytosol filtered & & 18 \\
through Sephadex G-50 & & 24 \\
plus buffer alone & 4220 & 18 \\
plus DTT & 5590 & 34 \\
plus NEM and DTT & 4210 & 46 \\
plus EAF & 8100 & 39 \\
plus EAF and DTT & 10,900 & 41 \\
plus NEM-treated EAF and DTT & 9150 & 51 \\
plus RNase & 9610 & 58 \\
plus RNase and DTT & 12,200 & 32 \\
plus NEM-treated RNase and DTT & 13,700 & 47 \\
plus S-protein & 7670 & 54 \\
plus S-protein and DTT & 11,100 & \\
plus NEM-treated S-protein and DTT & 12,700 & \\
\hline
\end{tabular}

Sephadex-filtered, MMTS-treated, transformed steroid-receptor complexes were incubated for $1 \mathrm{~h}$ on ice with the indicated additions and steroid binding and binding to DNA-cellulose were assayed as in previous experiments. For NEM-treatment, EAF (final concentration in assay $0.68 \mathrm{mg}$ protein/ml), RNase (final concentration $0.68 \mathrm{mg} / \mathrm{ml}$ ), and S-protein (at equimolar concentration to RNase) were preincubated at room temperature for $15 \mathrm{~min}$ with $1 \mathrm{mM}$ DTT, then $30 \mathrm{~min}$ with $3 \mathrm{mM}$ NEM, and then $10 \mathrm{mM}$ DTT was added to inactivate unreacted NEM. NEM-treated or non-NEM-treated preparations were added to the Sephadex-filtered, MMTS-treated cytosol as indicated.

A mimics the effect of the endogenous heatstable protein in permitting DNA binding. RNase S-protein, a catalytically inactive fragment of RNase A that lacks a 20 amino acid segment (RNase S-peptide) at the amino terminal [19], was found to be as effective as intact RNase in their system. As shown in Table 4, both intact pancreatic RNase and RNase S-protein promote DNA binding by Sephadexseparated, MMTS-treated, transformed receptors. An equimolar concentration of the 20 amino acid S-peptide cleavage product does not promote DNA binding.

As the intact RNase $\left(M_{r}, 13,700\right)$ and RNase S-protein $\left(M_{r}\right.$ 11,200) are similar to thioredoxin in both size and heat stability, it is possible that both preparations could be contaminated with thioredoxin. We have assayed both the RNase and the S-protein preparations by the insulin disulfide reduction method, however, and find no thioredoxin activity, even when RNase is present in the assay at a concentration that is 10 -fold higher than that employed in the experiment of Table 4. As shown in Table 5, neither the activity of the RNase preparations nor the activity of the thioredoxin preparation in promoting DNA binding is affected by treatment with $N$-ethylmaleimide. This again suggests that stimulation of receptor binding to DNA is a nonspecific effect that is unrelated to the presence of thiol moieties in either the thioredoxin or RNase preparations.

\section{DISCUSSION}

Two laboratories have reported that a heat stable component of rat liver cytosol promotes DNA bind- ing by glucocorticoid receptors that were partially purified or extensively purified without being submitted initially to thermal transformation $[11,17]$. As the effect of boiled cytosol in stimulating DNA binding can be replaced by partially purified or highly purified thioredoxin at concentrations that exist in the rat liver cytosol preparation (ref. 11, Table 2, Fig. 1), we have considered the possibility that thioredoxin might play a direct role in facilitating binding of the receptor to DNA. In the case of phage T7 DNA polymerase, it has been shown that thioredoxin acts as an accessory protein that endows the polymerase with the ability to function on double-stranded nucleic acids [13]. Although modification of the SH-groups in thioredoxin by $N$-ethylmaleimide destroys its activity on the phage polymerase, no thiol-disulfide exchange appears to take place after thioredoxin binds to the enzyme [13]. It is tempting to consider that an analogous interaction might be occurring between the glucocorticoid receptor and thioredoxin to affect the DNA binding activity of the receptor. Several observations, however, argue against any biochemically meaningful interaction between thioredoxin and the receptor: (1) the effect of partially purified thioredoxin in promoting DNA binding by MMTS-treated receptors in the presence of DTT is not affected by antithioredoxin serum (Table 3); (2) RNase A and RNase S-protein produce a similar increase in binding (Table 4); (3) treatment with $N$-ethylmaleimide does not affect the stimulation of DNA binding caused by either the thioredoxin or RNase preparations (Table 5).

It seems rather clear that there is also no biochemically meaningful interaction between RNase and the glucocorticoid receptor in promoting DNA binding. 
This is inferred from the fact that the catalytically inactive RNase S-protein promotes DNA binding by receptors, both in our system (Tables 4 and 5) and in the purified receptor system of Schmidt et al.[18]. At least, it can be said that the effect of the RNase preparation in our system is unrelated to the presumed catalytic effects of RNase on the size and DNA-binding activity of glucocorticoid receptors that have been reported in rat liver cytosol and other systems [20, 21].

Neither our observations nor the more recent observations of Schmidt et al.[18] support the "two step" model [17] of transformation in which a dissociated receptor must associate with a heat-stable cytoplasmic peptide in order to bind to DNAcellulose. It is entirely possible however that the receptor must associate with a metal in order to bind to DNA. It is known from studies of primary structure that the DNA binding domains of glucocorticoid and other steroid receptors $[22,23]$ contain cysteinerich motifs that by analogy with other proteins may constitute metal binding domains [24]. Similar motifs in the Xenopus transcription factor TF111A are thought to bind zinc which is required for DNA binding by that protein [25]. It is possible that the presence of such a trace metal could explain the effects of boiled cytosol and the partially purified thioredoxin and RNase preparations on DNA binding observed in our experiments and in the experiments published by Schmidt $e t$ al.[17, 18]. Schmidt $e t$ al.[17] have inactivated the DNA-binding factor activity in liver cytosol by trypsin digestion. In contrast, we have not been able to affect the activity of either boiled cytosol or the partially purified thioredoxin preparation by incubation with trypsin or chymotrypsin. This argues against a heat-stable protein factor being required for DNA binding and would be consistent with a metal effect.

Acknowledgements - This investigation was supported by Grant AM31573 from the National Institutes of Health and by grants from the Swedish Medical Research Council (13X-3529) and the Swedish Cancer Society. The authors would like to thank $\mathrm{Dr}$ Thomas Schmidt for making available the results of his experiments with RNase as they were in progress.

\section{REFERENCES}

1. Rees A. M. and Bell P. A.: The involvement of receptor sulfhydryl groups in the binding of steroids to the cytoplasmic glucocorticoid receptor from rat thymus. Biochim. Biophys. Acta 411 (1975) 121-132.

2. Bodwell J. E., Holbrook N. J. and Munck A. Sulfhydryl-modifying reagents reversibly inhibit binding of glucocorticoid-receptor complexes to DNAcellulose. Biochemistry 23 (1984) 1392-1398.

3. Bodwell J. E., Holbrook N. J. and Munck A.: Evidence for distinct sulfhydryl groups associated with steroidand DNA-binding domains of rat thymus glucocorticoid receptors. Biochemistry 23 (1984) 4237-4242.

4. MacDonald R. G. and Leavitt W. W.: Reduced sulfhydryl groups are required for activation of uterine progesterone receptor. J. biol. Chem. 257 (1982) 311-315.
5. Wilson E. M., Wright B. T. and Yarborough W. G.: The possible role of disulfide bond reduction in transformation of the $10 \mathrm{~S}$ androgen receptor. J. biol. Chem. 261 (1986) 6501-6508.

6. Kalimi $M$. and Love $K$.: Role of chemical reagents in the activation of rat hepatic glucocorticoid-receptor complex. J. biol. Chem. 255 (1980) 4687-4690.

7. Sando J. J., Nielsen C. J. and Pratt W. B.: Reactivation of thymocyte glucocorticoid receptors in a cell-free system. J. biol. Chem. 252 (1977) 7579-7582.

8. Leach K. L., Grippo J. F., Housley P. R., Dahmer M. K., Salive M. E. and Pratt W. B.: Characteristics of an endogenous glucocorticoid receptor stabilizing factor. $J$. biol. Chem. 257 (1982) 381-388.

9. Grippo J. F., Tienrungroj W., Dahmer M. K., Housley P. R. and Pratt W. B.: Evidence that the endogenous heat-stable glucocorticoid receptor-activating factor is thioredoxin. J. biol. Chem. 258 (1983) 13658-13664.

10. Grippo J. F., Holmgren A. and Pratt W. B.: Proof that the endogenous, heat-stable glucocorticoid receptoractivating factor is thioredoxin. J. biol. Chem. 260 (1985) $93-97$

11. Grippo J. F., Tierungroj W., Boborodea V., Pratt S. E., Carlson M. D. and Pratt W. B.: The role of thioredoxin in determining the steroid-binding state of the glucocorticoid receptor. In Thioredoxin and Glutaredoxin Systems: Structure and Function (Edited by A. Holmgren, C. I. Branden, H. Jornvall and B. M. Sjoberg). Raven Press, New York (1986) pp. $377-390$.

12. Tabor S., Huber H. E. and Richardson C. C.: In Thioredoxin and Glutaredoxin Systems: Structure and Function (Edited by A. Holmgren, C. I. Branden, H. Jornvall and B. M. Sjoberg). Raven Press, New York (1986) pp. 285-300.

13. Huber H. E., Russel M., Model P. and Richardson C. C.: Interaction of mutant thioredoxins of Escherichia coli with the gene 5 protein of phage T7. The redox capacity of thioredoxin is not required for stimulation of DNA polyerase activity. J. biol. Chem. 261 (1986) 15006-15012.

14. Holmgren A.: Thioredoxin catalyzes the reduction of insulin disulfides by dithiothreitol and dihydrolipoamide. J. biol. Chem. 254 (1979) 9627-9632.

15. Holmgren $A$. and Luthman $M$.: Tissue distribution and subcellular localization of bovine thioredoxin determined by radioimmunoassay. Biochemistry 17 (1978) 4071-4077.

16. Grandics P., Miller A., Schmidt T. J., Mittman D. and Litwack G.: Purification of the unactivated glucocorticoid receptor and its subsequent in vitro activation. J. biol. Chem. 259 (1984) 3173-3180.

17. Schmidt T. J., Miller-Diener A., Webb M. L. and Litwack G.: Thermal activation of the purified rat hepatic glucocorticoid receptor. Evidence for a two-step mechanism. J. biol. Chem. 260 (1985) 16255-16262.

18. Schmidt T. J., Diehl E. E., Davidson C. J., Puk M. J., Webb M. L. and Litwack G.: Effects of bovine pancreatic ribonuclease $\mathrm{A}, \mathrm{S}$ protein, and $\mathrm{S}$ peptide on activation of purified rat hepatic glucocorticoid-receptor complexes. Biochemistry 25 (1986) 5955-5961.

19. Richards F. M. and Vithayathil P. J.: Preparation of subtilisin-modified ribonuclease and the separation of the peptide and protein components. J. biol. Chem. 234 (1959) $1459 \ldots 1465$

20. Tymoczko J. L. and Philips M. M.: The effects of ribonuclease on rat liver dexamthasone receptor: increased affinity for desoxyribonucleic acid and altered sedimentation profile. Endocrinology 112 (1983) 142-149.

21. Kovacic-Milivojevic B., La Pointe M. C., Reker C. E. and Vedeckis W. V.: Ribonucleic acid is a component 
of the oligomeric, transformed mouse AtT-20 cell glucocorticoid receptor. Biochemistry 24 (1985) 7357-7366.

22. Hollenberg S. M., Weinberger C., Ong E. S., Cerelli G., Oro A., Lebo R., Thompson E. B., Rosenfeld M. G. and Evans R. M.: Primary structure and expression of a functional human glucocorticoid receptor CDNA. Nature 318 (1985) 635-641.

23. Danielson M., Northrop J. P. and Ringoid G. M.: The mouse glucocorticoid receptor: mapping of functional domains by cloning, sequencing and expression of wild-type and mutant receptor proteins. EMBO J. 5 (1986) 2513-2522.

24. Berg J. M.: Potential metal binding domains in nucleic acid binding proteins. Science 232 (1986) 485-487.

25. Miller J., MaLachlan A. D. and Klug A.: Repetitive zinc-binding domains in the protein transcription factor IIIA from Xenopus oocytes. EMBO J. 4 (1985) 1609-1614. 